\title{
SCYTHIAN FEMALE WARRIORS IN THE SOUTH OF EASTERN EUROPE
}

\section{SCYTYJSKIE WOJOWNICZKI W POŁUDNIOWEJ CZESŚCI EUROPY WSCHODNIEJ}

\author{
Elena Fialko \\ Institute of Archaeology \\ National Academy of Science of Ukraine, Kiev, Ukraine \\ ofialka@ukr.net
}

\begin{abstract}
The article is devoted to the funerary complexes of Scythian female warriors in the territory of the European Scythia. Types and sizes of graves, as well as the nature of the funeral rite of Amazons correspond to Scythian canons and de facto do not differ from men's graves The analysis of the funerary inventory allows us to date them within the second half of the 7th till the 2nd centuries BC.
\end{abstract}

KEY WORDS: Amazons, barrows, burials, funeral ceremony, Scythians, Eastern Europe, Ukraine

Amazons as beautiful horsewomen and female warriors are constantly mentioned among the famous heroes of the ancient Greek mythology. Greeks very appreciated their fighting qualities and called the troops of the warrior women to help them during the battles with the enemy.

The Amazons are mentioned in many works of the ancient authors. They are often related to the Scythians or Scythia. Among well-known names of ancient authors are Herodotus, Hippocrates, Lysius, Palaephat, Strabo, Diodorus Siculus, Pompeius Trogus, Plutarch etc.

There are two different opinions what Amazons are. More often they are referred seen as fierce, fighting women equal to men; they participated in battles until the marriage. More seldom they are described as the kingdom of husband-killers. There was either lack of men or they were treated as slaves and were used just to have progeny. 
From the narrative sources we learn that Amazons were daughters of Ares, God of War, and the Nymph Harmonia. They worshipped Ares and Artemis, the Greek goddess of the hunt. The Amazon queens built up the temples to these gods. They also worshipped Zeus, Poseidon and Hephaestus.

According to Kallisthenes (III, 27) Alexander Macedonsky wrote to his mother, that the Amazons were tall, beautiful, healthy, sharp and witty ${ }^{1}$. Diodorus Siculus (II, 44, 45; XVII, 77, 2) noted their extraordinary strength, intelligence, great warrior skills and beauty. The information on clothes of female warriors is inconsistent. They had two types of garments. According to Herodotus, the Amazons had the same colorful clothing that men were wearing (Herod IV, 116). They made helmets, overcoats and belts out of wild animals' skin (Strabo XI.V, 1). Eusebius Hieronymus (II, 37), unlike others, wrote that Amazons would provocatively reveal their breast, arms and legs to lure their male enemies.

Most authors agree that they were armed with bow and arrows, battle-axe, javelin, spear and lasso. Of protective equipment they had light moon-shaped shields. Whatever Amazons do - fight, shoot a bow or throw the javelin - they do it on a horseback. From early childhood girls were trained to use weapons, ride a horse and hunt (Hp. Aer. 24; Mela 1. 19. 114; Diod. 2. 45-46; Pind. N. 3. 38; Strabo 11. 5. 1)

Young girls had to kill three enemies before they could get married. After that they would only use weapon in the event of general mobilization.

According to some authors, Amazons inhabited Northeast of Minor Asia (Fermodont riverside near Femiskira).

The first most detailed story about women-mariticides (Oíó $\pi \alpha \tau \alpha)$ was written by Herodotus (Herod. IV, 110-112). According his version Greeks clashed with Amazons on the river of Thermodontos. After the battle, ships with captive Amazons reached Scythia - Maeotic Lake (the Sea of Azov), near port of Kremny. They went ashore, stole horses and began plundering Scythian lands. At first, the Scythians thought Amazons were men. Then they camped. Later on, Amazons mixed with young Scythians and moved to Tanais River (the river of Don), so their successors were called Savromatians.

Thus, Herodotus in fact identifies three stages in the history of the Scythian Amazons. 1 - Pre-Scythian period (independent kingdom of women); 2 - Scythian period (obtaining of a new homeland, adaptation to new conditions and different lifestyles, the conquest of social equality) and 3 - Sauromathian period (new resettlement, family relationships with equal and independent position). Herodotus, unfortunately, did not mention how long the Scythian period last in the life of the Amazons did. We could only conclude that to start the warrior women had to win their living space. Then it took a while to find a partner for everyone. Further, they

\footnotetext{
${ }^{1}$ Here and further it is cited by: Латышев В. В. Известия древних писателей о Скифии и Кавказе // ВДИ. 1947. № 2 (20); 1949. № 1 (27).
} 
spent certain period to create a family and, most importantly, to adapt to the local customs and to overcome the language barrier. Besides, probably not all Amazons gone to the east, a certain part of them could stay in Scythia.

By works of ancient art we can determine the Amazons' appearance. Judging from stone statues and pictures on temple bas-relieves, mosaic floors, sarcophagi and toreutics works, jewelry and other works of art. Amazons were young females with long flying hair or in light helmet and short semitransparent Greek-type clothing. In vase paintings, they often resemble Herodotus' characters wearing men's Persian-type clothing. Usually this is a maid in a man's attire (kaftan and tight trousers with strips) that fits slender body; bare feet or soft short boots (scyphics) on; soft cap occasionally with protective "flaps", on the sides and back. Young women were always armed either with bow and quiver with arrows, or with spear or javelin. Moon-shaped shield in the pictures is common.

Independent figures of Amazons are rarely represented in works of art. As usual, they are the participants of battles. Two options of these stories are known. Amazonomachia plot was widespread and reflected the artistic direction and passion of Greeks and Romans, and the barbaric population. Griffonomachia subjects are more prevalent in the periphery of the ancient world. Here, the Amazons perceived as servants of the Great Goddess and embodied connections with the world beyond the grave. Probably, these images illustrate some local versions of myths about the Amazons, which are not preserved in the narrative sources.

Archaeological excavations within the second half of the 20th century were conducted in Southern Ukraine, which was once inhabited by ancient nomadic peoples - Cimmerians, Scythians and Sarmatians. As became evident, women carried arms and participated in armed conflicts like men did exist among the nomads. For this reason they were buried the same way as male warriors. Recent archaeological findings show that in Scythian times female graves with weapons were widely spread throughout south area of Eastern Europe. They are known in the Dnieper Forest-steppe, the Lower Don, Northwestern Pontic area, in Caucasus, in Kuban and in other territories (Ганіна, 1958; Ганина, 1960; Брашинский, 1968, pp. 88-89; 1973, pp. 60-61; Брашинский, Демченко, 1969; Мелюкова, 1975, pp. 79-80; Максименко, 1983; Галанина, 1985, р. 161; Андрух, Тощев, 1999, 2004; Андрух, 2001; Марченко, Житников, Копылов, 2000; Гуляев, 2002, 2005, 2010; Guliaev, 2003; Гуляев, Савченко, 2004; Копылов, Яковенко, Янгулов, 2004; Янгулов, 2007, 2008, 2008a; Фиалко, 2011, 2012b, 2013; Прокопенко, 2014, 2014a etc.).

The graves of female warriors constitute the quarter of the total number of Scythian graves with (Бунятян, 1982, p. 184). That means that every fourth Scythian warrior of Northern Pontic Area was woman. More than 270 female warriors' graves were found on the territory of European Scythia, and particular in the south area of Ukraine. The Amazons' anthropologic type as well as their funeral ceremonies was identical to those of the rest of Scythian population (Фиалко, 1991). 
The third part of all mound burials was primary, the rest were secondary ones of Bronze Age. Barrows were usually 0.2-1.2 m high. For the exception of three barrows, their height accounted 1.6; 2.3 and $2.5 \mathrm{~m}$ (kurgan 11 near Ordzonikidze, kurgan 11 near L'vovo village, kurgan 1 near Soldatskoe village). There were three types of burials (fig. 1). Undercuts dominated (over 60\%), less common were catacombs (some 30\%) and pits (below 10\%).Women were laid extended on their back. The Western orientation of the deceased was prevalent (Фиалко, 1991).
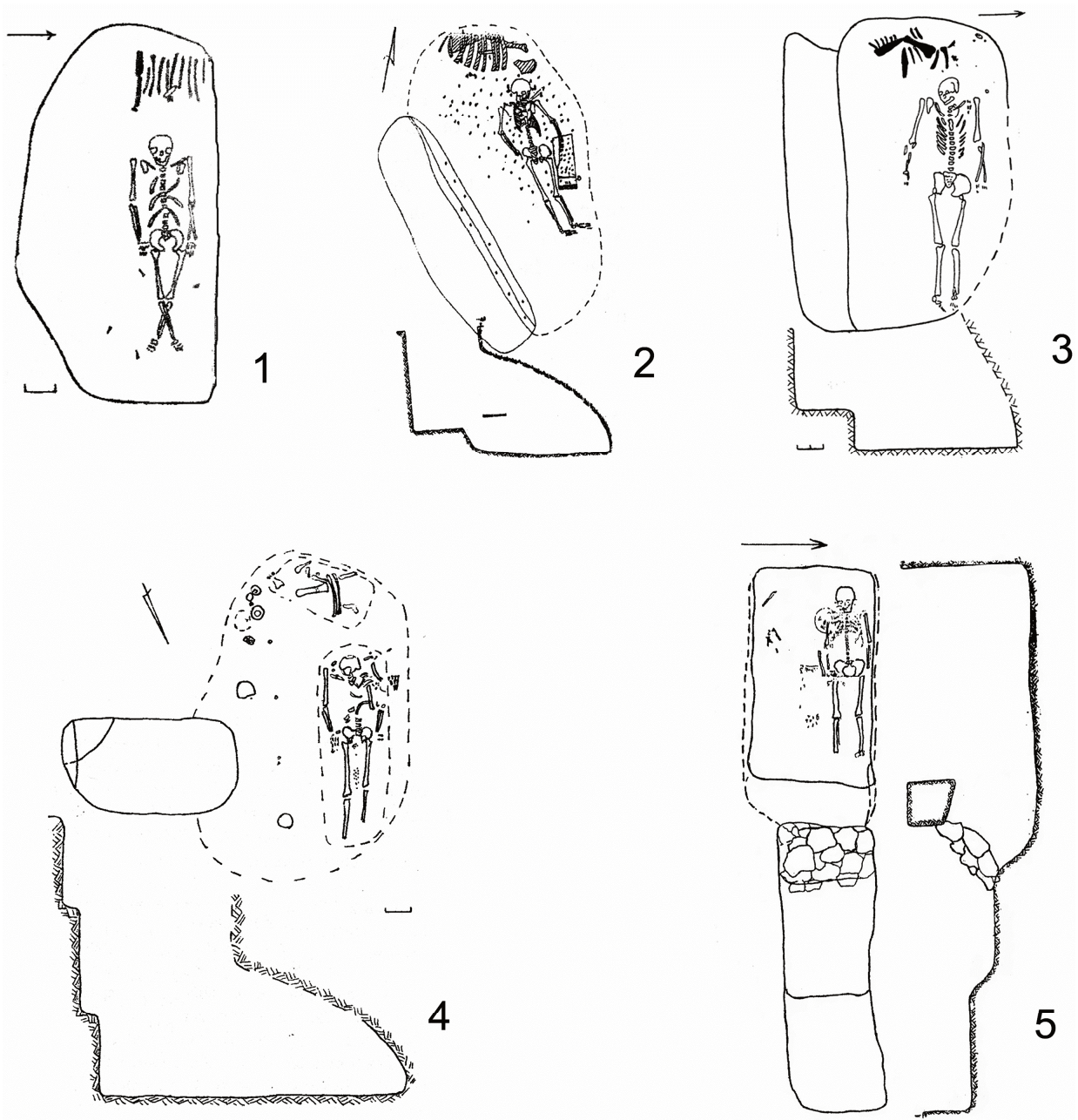

Fig. 1. The types of female burials with weapons. Cemetery Mamay-Gora: 1 - kurgan № 40; 2 - kurgan № 139; 3 - kurgan № 54; 4 - kurgan № 16; 5 - kurgan № 100 (from Андрух, Тощев 1999; 2004; 

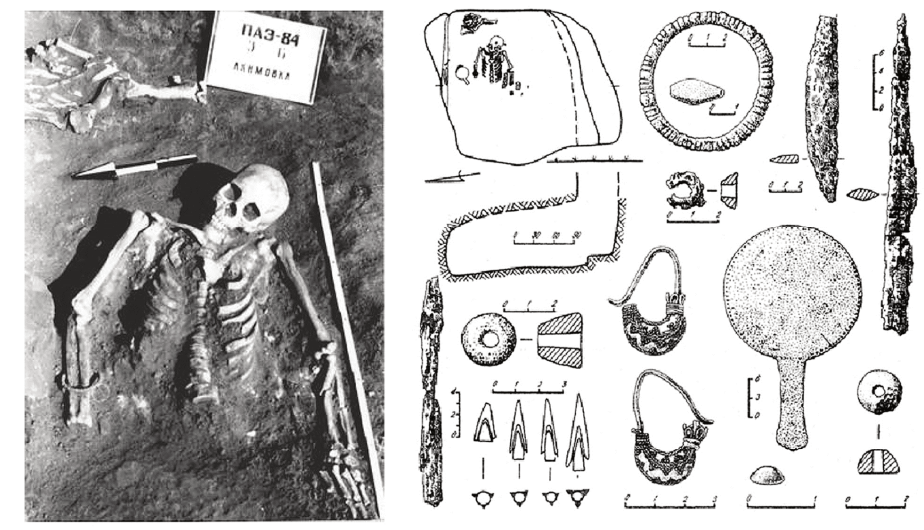

A
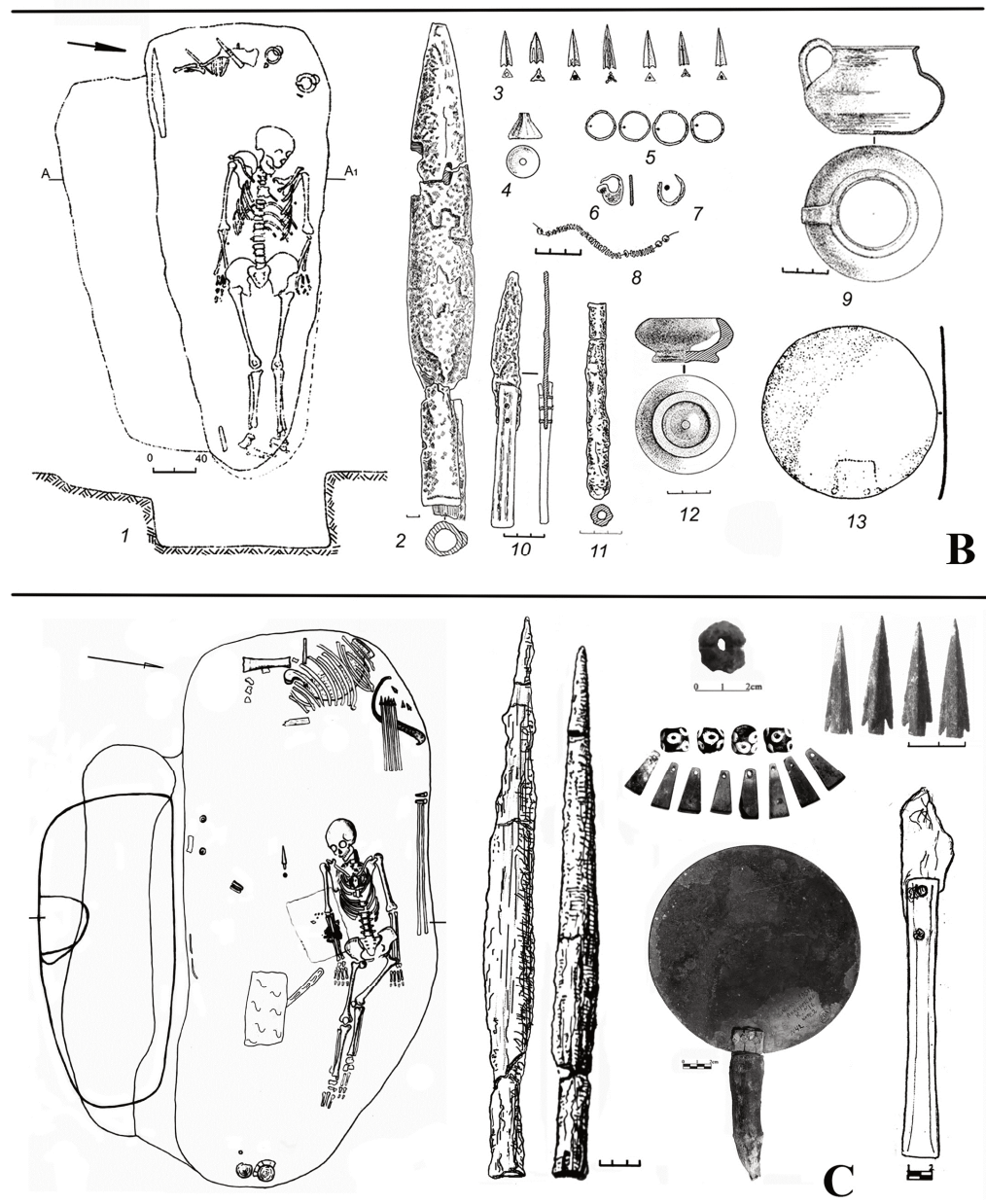

Fig. 2. The plans of Amazons' burials and grave goods from them: A - kurgan 3 near Akimovka village; B - kurgan 9 of Chertomlyk cemetery; C - kurgan16 near Novo-Filippovka village 
Grave goods can be divided into three groups: 1 - universal, 2 - female and 3 male. The universal group includes meat dishes on a wooden platter or tray, along with an iron knife, and various vessels. Female group is represented by mirrors, earrings, beads and necklaces, bracelets and rings, cosmetics and stone plates or dishes. But also the tools of the labour-spindles, needles and awls. Male group includes the weapons-arrows, spears and javelins, sling stones, protective armor, horse bridle, personal ornaments - neck-rings and rings. The latter group includes also bronze cauldrons. As a general rule combination of those three sets identified the Amazon 'grave (fig. 2). However, it should be noted that a wide range of things from all three groups in the complexes is quite rare. This is due to the fact that most of the graves were robbed in ancient times.

There was a limited choice of weapons (fig. 3). Practically every Amazon had a bow and set of arrows. However the bows are rarely kept in the Scythian tombs. Among the women's graves we can mention the wreckage of a wooden bow in the burial mound n. 2 of the $20^{\text {th }}$ kurgan of the Nikopol mound fields (Граков, 1962, p. 67). The arrows sets in the graves were represented with the quivers, in separate bundles outside quiver or/and by single specimens. Only the arrow-heads were preserved, shafts and their plumage mouldered with time. Short parts of the shaft are sometimes noted on the sleeves of the arrow-heads. Scythians were armed with arrows with the arrow-heads made of bronze, iron, wood and bone. Bronze ones dominated quantitatively. There was no a norm of the quantity of the arrows in one set. This was the case for all quiver sets of the Scythians, regardless of gender and social rank of their owner (Грицюк, 2009, p. 63). There could be only a few units, several dozens or hundreds arrows in the accompanying sets of the Amazons' items. The maximum number was 135 arrows, they were found in the kurgan n. 38 near Lyubimovka village (Kherson region.).

Many Amazons were armed with spear or javelin (or both). However spears were quantitatively prevailed. They were using the short spears tipped with iron and iron ferrules on the end of a wooden shaft. One can establish the length of a spear or a javelin due to the location of their metallic parts that were found in situ in the tomb. For example, the total length of the spear from the burial mound n.1 from the kurgan n. 5 near Novoie village (Zaporizhzhya region) was 2.07 m (Фиалко, 1987, p. 174). Two spears from the burial mound of the kurgan n. 13 of the Steblevskiy burial ground (Cherkasy region) have almost the same length $(2.1 \mathrm{~m})$ (Скорый, 1997, p. 89). This fully corresponds to the size of the usual Scythian spears and javelins (Мелюкова, 1964, p. 43; Черненко, 1988, 1991, p. 133). There were usually one or two spears in one funerary complex (in approximately equal proportions). Only in one case (burial mound n. 2 in the kurgan near Novoie village) woman was buried with three spears.

There were less javelins than spears. This tendency is typical for the Scythian weapons in general (Грицюк, 2009, p. 66). Typically, they were one javelin per grave. 


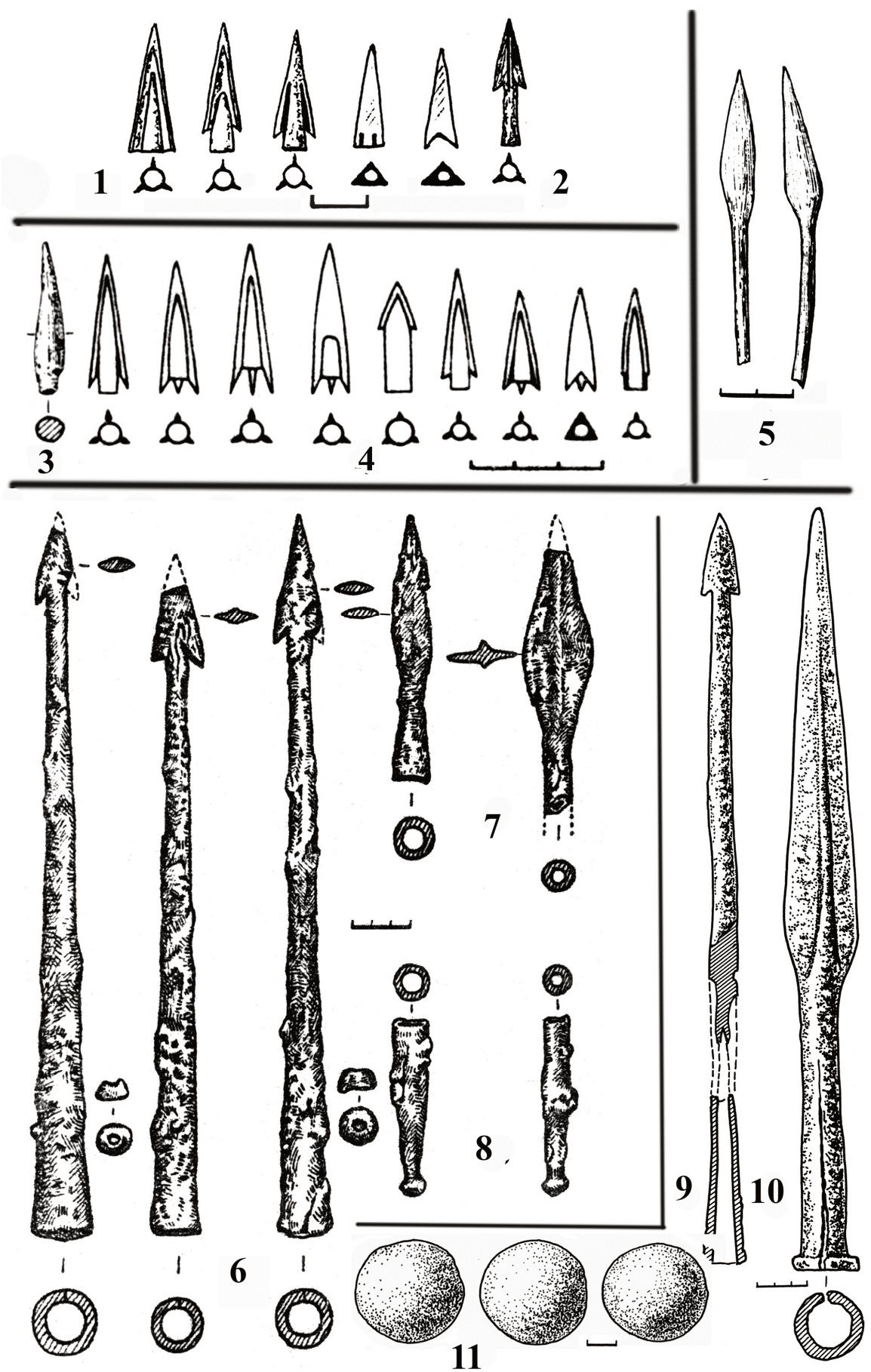

Fig. 3. The assortment of weapons from female graves 
In half of the cases a javelin were matched with a spear. In one case there were two javelins in the grave (kurgan n. 11 near L'vovo village), in another there were three of them (kurgan n. 13 Steblevskiy burial ground). Design features, tactical and technical characteristics of these weapons indicate that Amazons preferred throwing spears and javelins. The end caps of the spears and javelins were often kept in leather or woven covers, tightened with a cord.

Apparently, the Amazons were also armed with a sling - another type of missile weapon, designed for the long distance fights. Only stones, from one to five in the set, are conserved in the graves. The sling was used by both the infantry and the cavalry. The unpopularity of this weapons among women, could be possibly explained by its heavy weight.

Melee weapons are not typical for the Amazons. Battle-axes were found in only two burial (n. 13 in the ground burial Skelky in Zaporizhzhy region and kurgan n. 14 y in Glinoe Village in Moldova) (Попандопуло, 2011; Синика, Алемша, 2000, p. 45). This could seem odd, since on the various works of art, the Amazon have often just the light axes in their hands. However in general this weapon is not popular in the Scythian environment.

Iron swords and daggers were the main weapon for the close fight in the army of the Scythians. But only three graves on the territory of modern Ukraine contained iron swords (kurgan 6 near Mar'evka village, kurgan 38 near Ljubimovka village, kurgan 22 near Vinogradnoje village). At the same time in Elizavetovskiy burial ground on the Don the swords were found in seven female graves. It is important to emphasize that the five of them contain a complete set of offensive armament arrows, a spear and a sword (Янгулов, 2008, p. 22). Scythians were armed with two types of bladed weapons: a short sword or dagger (from 17 to $50 \mathrm{~cm}$ ) and a long sword (from 50 to $85 \mathrm{~cm}$ or more) (Мелюкова, 1964, p. 46; Артамонов, 1974, p. 40; Горелик, 1993). The Amazons seem prefer the long iron swords.

They had neither protective armors nor war belts. Only three graves contained bronze war belts (kurgan 16 near Novofilippovka village, kurgan 11 near L'vovo village, kurgan 423 near Zurovka village) (fig. 2-C). Inexpressive fragments of iron armor preserved in two graves (kurgan 30 of Chertomlyk cemetery, kurgan 5 of Mamaj Gora cemetery). It is not excluded that the protective armor of ordinary warriors was made of leather or felt. From the above, it might be assumed that females formed light armed cavalry.

The kurgan 5 near Zelenoje village is the exception. There were three graves of girls with the weapon in it (fig. 4). A mound of a teenage girl was the main mound in the kurgan. Her outfit includes spear, javelin, scale armour, three-stone for a sling, a mirror, a quern with wooden beater, a necklace with glass beads. Little girls from two other graves had only glass beads and one and three arrows. Judging by the layout, an Amazon with two servants were buried in this kurgan (Фіалко, 2012a). This confirms the evidences of ancient authors, who claim that Amazons were trained 
the military affairs from the early childhood. The kurgan is unique, because there were no other warriors in full ammunition in an array of Scythian monuments.
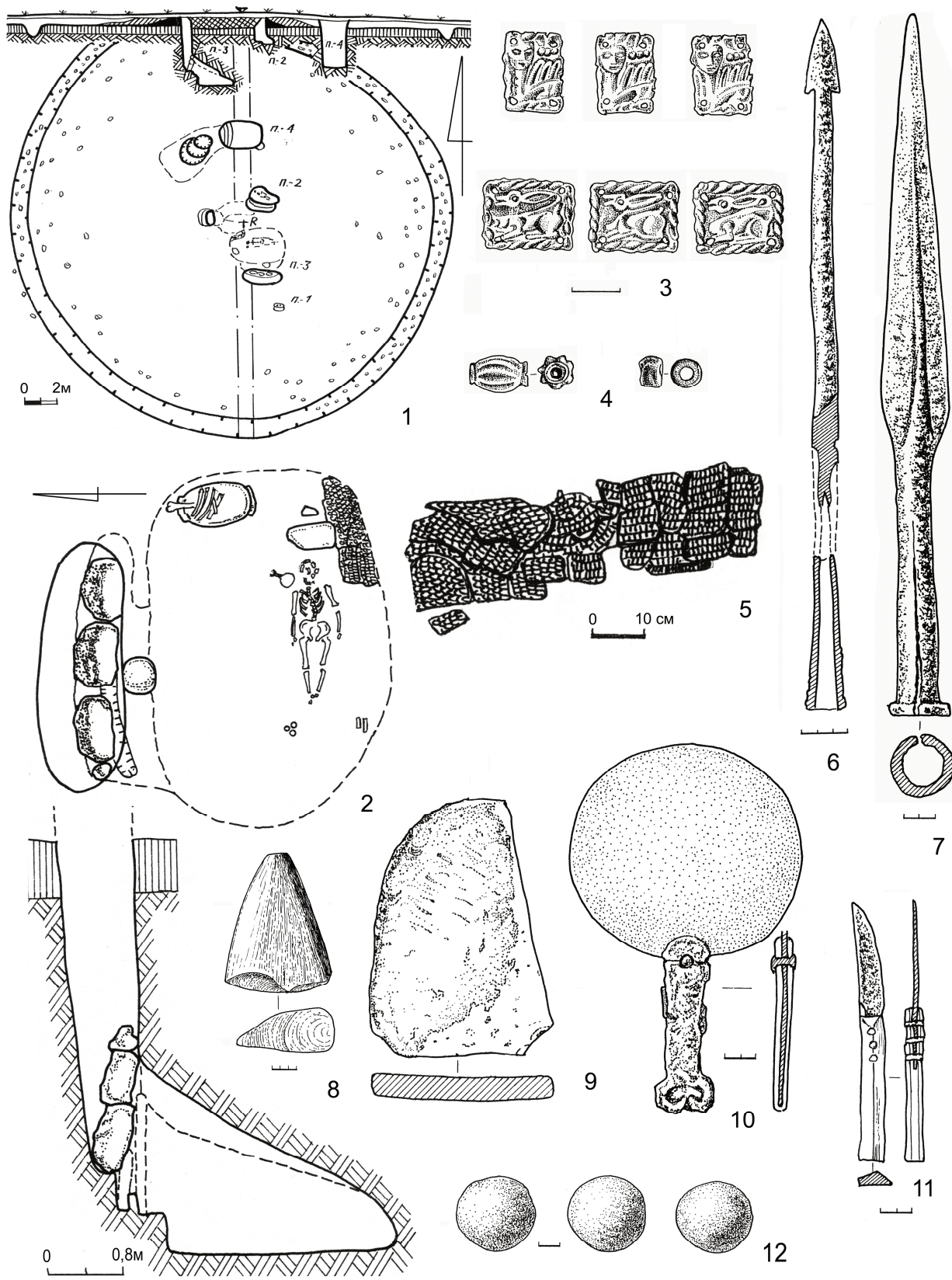
However female warriors were never buried with their battle horses. Only one grave contained the remains of a whip. The other four graves contained the fragments of the horse bridle and one grave had actually a horse. There were only one case with the horse bridle in the steppe region (kurgan n. 2 near Novoie village in Zaporizhzhya region). Another three graves with bridle are located in the foreststeppe (kurgan 447 near Zurovka village, kurgan 35 near Bobritsa village, kurgan 13 of Steblev cemetery). This situation seems rather strange and it is difficult to explain. According to Hippocrates married Savromatian women saddled the horses only in the case of war. Probably after their landing at the Azov Sea coastal the Amazons initially waged war on the horsebacks. With time (since the second half of the fifth century BC according to archaeological data) amazons became less aggressive and independent and participated in Scythian campaigns and defensive battles as needed in detachments of light infantry. Perhaps they were mercenaries, for example, members of the nobility of the forest-steppe regions, which are periodically attacked by another wave of nomads. Perhaps they were also mercenaries, for example, for the members of the nobility of the forest-steppe regions, which were periodically attacked by another nomads. Presumably the female warriors from the kurgan n. 9 near Staryi Merchyk and kurgan n. 25 near Grishkovka (Kharkiv region) could be considered as mercenaries (Фиалко, 2011). Such an assumption is quite plausible, given the fact that both kurgans are related to forest-steppe segment of $\mathrm{Mu}$ rawski (Окатенко, 2006, p. 282).

Among the animals we can only mention the dog, that was lying at the entrance of the burial chamber in the tomb of kurgan n. 5 in Mamay-Gora cemetery, which had some similarities with the small south-russian shepherd.

The Scythian Amazons suit was determined by tradition, a way of life and their habitats. Written and artistic sources show that militant women preferred Scythian men's clothing. However, according to archaeological data, they added ordinary women's jewelry to it. Necklaces, earrings, bracelets, rings and necklaces were the typical jewelry. Pins and fibulae were rarely used. The metal neck-rings were an exception, because it was an attribute of the male commander. Some of Amazons complemented their costumes by sewn metal plates and removable jewelry (Фиалко, 2013a).

Archaeological sources bear testimony of social stratification. This is also proved by difference in size of burial complexes and set of grave goods. For the most part, those were members of so-called middle class. However there are several Amazons 'burials with golden jewelry - ear-rings, finger rings and expensive import blackc slip and red-figured pottery (for example kurgans 2 and 3 near Akimovka village, kurgan 16 from cemetery Mamay-Gora etc.) (fig. 2-A). They indicate a higher social status of the buried women. Besides, sometimes the set of equipment included bronze cauldron (kurgan 38 near Ljubimovka village, kurgan 8 near Volchansk village) and (or) metal neck-ring (kurgan 16 from Mamay-Gora cemetery). 
These things marked the burials of commanders - women, who led the military subdivision. Thus among the Amazons stands out several social groups: the ordinary combatants, the middle link (successful warriors), highborn (rich) Amazons, the commanders (leaders) and the security guards from the retinue (Fialko, 2012).

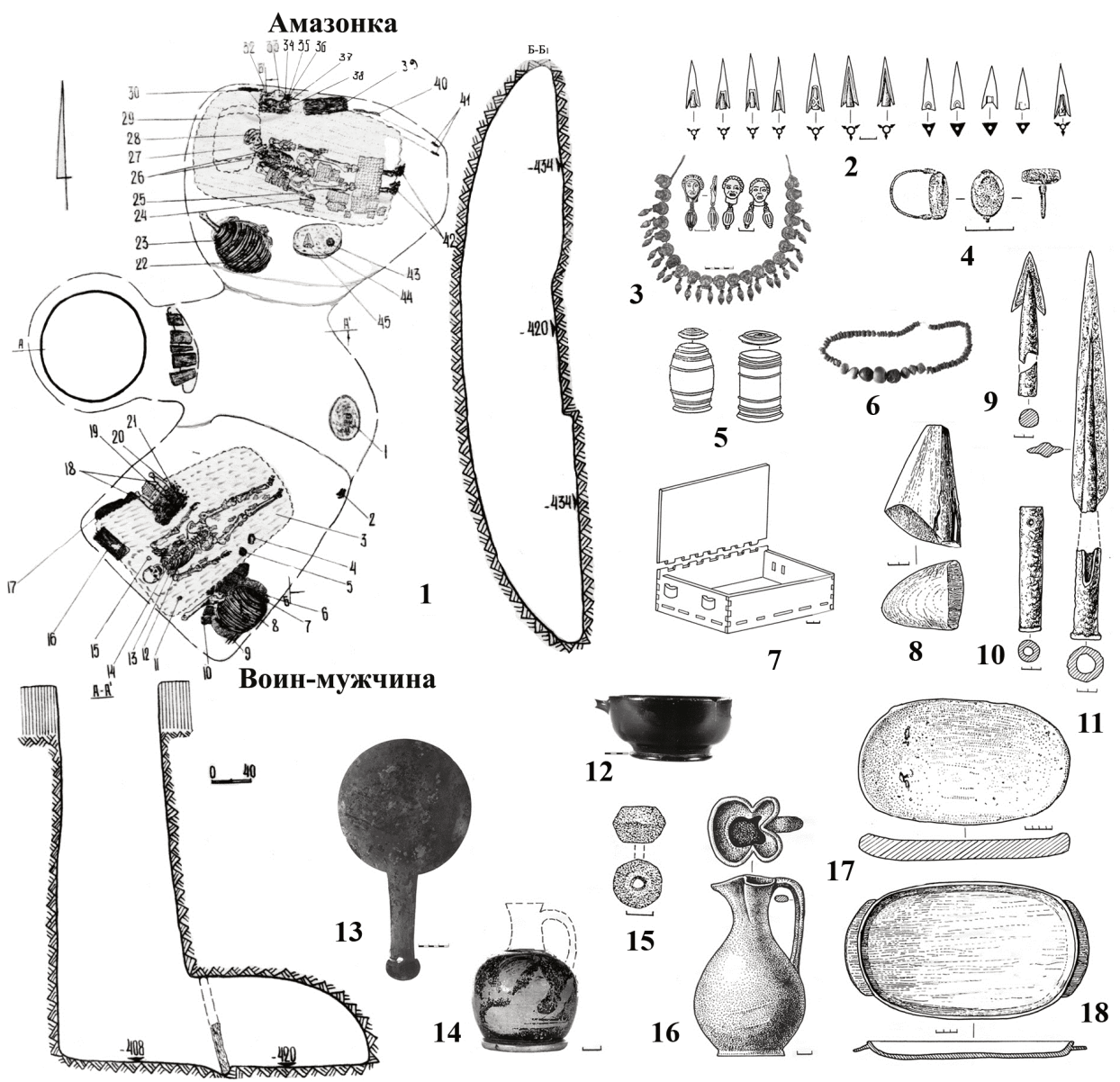

Fig. 5. Kurgan 2 near Zelenoje village: burial and grave goods

The tomb from kurgan 2 at Zelenoje village is especially interesting for us. The Amazon was buried in one grave with a man, but each had a separate chamber (fig. 5). Both are clearly representatives of the social elite. The woman has a leather patch on her head and leather boots with embossed ornamentation. The jewellery was represented by the gold necklace, the silver ring and the bracelet of glass beads. In a set of things were jewellery box with mirror, two pyxides, spindle and an awl; 
a quern with wooden beater, three imported vessel, spear and quiver with 107 arrows. Probably it was a couple buried in the grave. The situation in this funeral complex shows us clearly that Scythian Amazons had the same social status as the men (Фиалко, 2012). A similar situation is observed in the funerary complex of kurgan 7 near Kut village (Березовець, 1960, pp. 53-55). Here we can recall eight graves of cemetery Elizavetovskoe too. Armed man and woman were buried at the same time in each of these graves (Копылов, Яковенко, Янгулов, 2004, p. 54). For example, in a mound 51 inventory of both buried - men and women contain a complete set of offensive weapons (Янгулов, 2008a, p. 26). However, there are cases when the social rank of the Amazon was clearly above the rank of the other male warriors who were buried in the same cemetery. A separate mound, superior in quantity and quality set of tools and the presence of relevant markers of status items in this collection prove this. Kurgan n. 38 near Lubimovka village, kurgan n. 8 near Volchansk, kurgan n. 5 near Velyka Znamenka, kurgan n. 16 of Mamay-Gora cemetery, kurgan n. 5 near Bulgakovo and some others can be mentioned among these burial complexes. The presence (in addition to weapons) of the bronze cauldrons, metal (especially gold or silver) neck-ring and gold jewelry in the sets of funerary items of the Amazons allows us to identify their owners as the commanders of military units (Фиалко, 2012, pp. 38-40).

The burials of the Scythian female warriors were not part of isolated groups or individual burials, they were dispersed among male burials. Number of female burials with weapons in cemeteries was rather uneven. In some cemeteries such burials were represented by whole groups (cemetery near Lyubimovka village, cemetery of Chertomlyk, cemetery near Zelenoje village, cemetery Mamay-Gora, Skelki cemetery, Elizavetovsky cemetery). In several groups there were from one to three burials, in other they were absent. The most representative series of graves was discovered in the largest cemetery in the north Pontic area - Mamay-Gora. Among the 317 Scythian burials 12 belong to the Amazons. Given the fact that the cemetery studied 110 male and 135 female burials, we can conclude that every tenth soldier was a woman. At the same time, every 11-th woman had a weapon and performed military service. Skelki cemetery, located on the bank of the Kakhovka water reservoir, is one of the largest necropolises without mounds of the Lower Dnieper area in the Scythian times. Fifty-three Scythian graves were investigated there. Almost a half of the women (11) were armed. Moreover there was a little girl buried with weapons. There were 22 warriors that were buried in the cemetery, consequently every second soldier was a woman and every third woman carried weapons. Among the investigated necropolises of Steppe Scythia the highest percentage of the Amazons graves was registered in the cemetery of Skelki. At the same time in the Don region, 147 burial complexes with armaments were excavated in Elizavetovskoe cemetery. And 35 belong to the Amazons. 
Warrior females were not all of the same age - it ranged from 16 to 60 , still half of them were young, aged 25-35 (Фиалко, 1991). All graves were single almost without exception. In the steppe region only four of them entombed young woman and a baby (kurgan 16 in the group of Chertomlyk, kurgan 48 in the group of Shirokoje-2, kurgan 13 near Ordzonikidze, kurgan 14 near Vyshetarasovka village). And four of them were accompanied by servants (kurgan 14 near Vyshetarasovka village, kurgan 12 in the group Nosaki, kurgan 18 near L'vovo village, kurgan 48 near Ljubimovka village). Only ten of the females buried with arms were sixty (an advanced age for Scythian period), all unmarried, as evidenced by weapons occurrence. That must have been relatively peace time of Scythian history, so they were unable to kill enemies.

As for the Amazons' original inhabitation, it is supposed to be the city of Femiskira (Minor Asia) at the mouth of River Fermodont (Termodont), the latter was identified with River Therma Chai flowing into Black Sea.

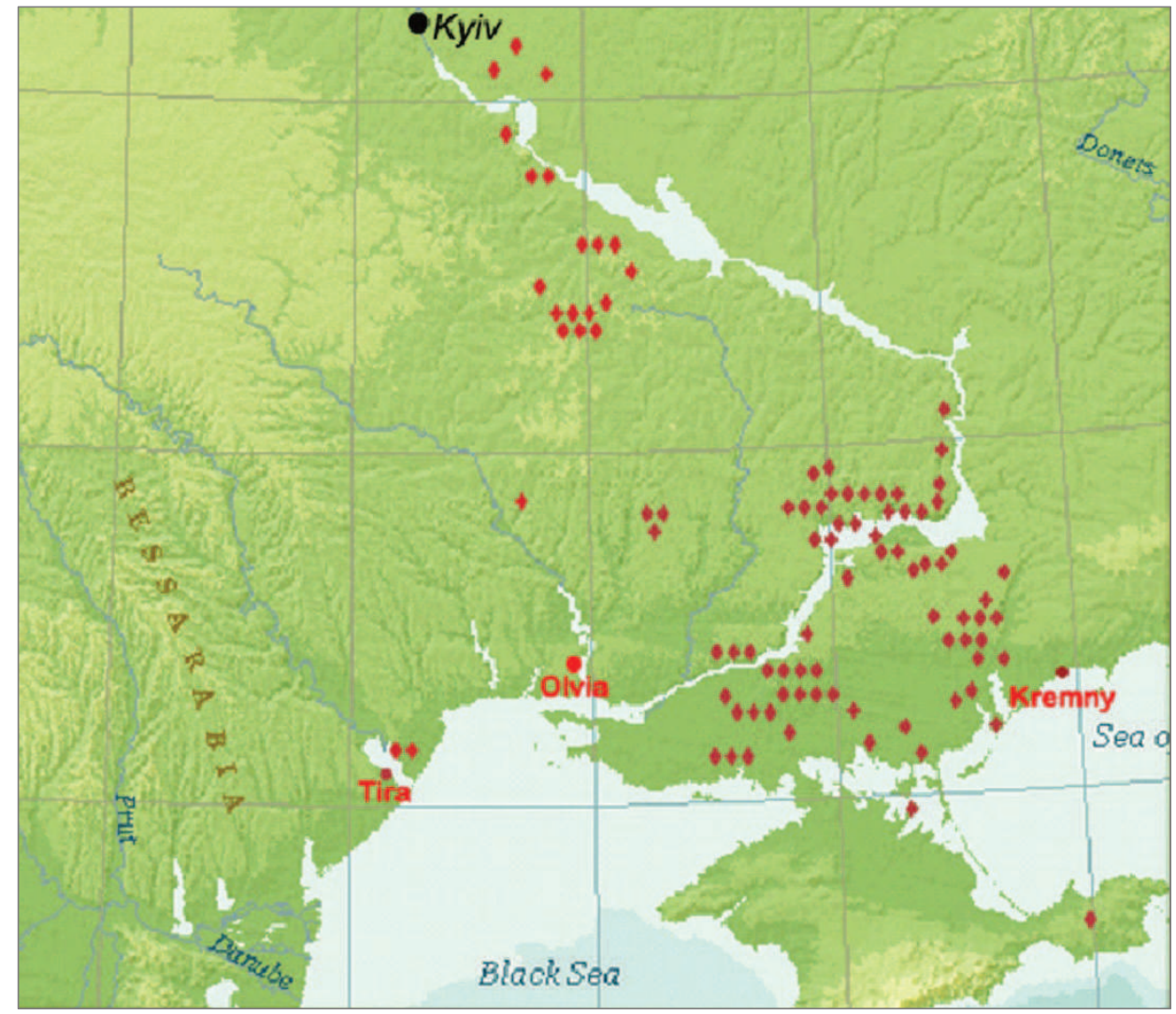

Fig. 6. Spread of female graves with weapons throughout south area of Ukraine 
Three basic concentrations of female graves with arms (dated the 5th-half of the 4th century B.C.) exist in Pontic Steppe zone (fig. 6). The big one is in the northwest Azov Sea Region - at the mouth of Molochnaya River (near port of Kremny), the smaller one - along low Dnieper left-bank, and the greatest one - along the Dnieper right bank, up to the mouth of Bazavluk River (Фиалко, 1991, fig. 7).

At first glance, we have a relative agreement with Herodotus account. Numerous graves of female warriors were found in Azov Sea Region - place of their arrival to Scythia. These graves probably mark the beginning of their route associated with their battles with Scythians. Two other groups trace their inland penetration. However, given the chronology of monuments, such a situation can be considered as a fortunate coincidence.

Numerous graves of female warriors for the specified period were also found along Don River (near Kolbino and Ternovoje villages). These are probably the tombs of the Amazons, who had gone along with the young Scythians to the east across Tanais River. It seems quite plausible especially if we consider the later dates of the funerary complexes of Don Region.

Despite of the numerous facts, that seem obvious, the question of the direct participation of the Scythian women in combat is still open. The most compelling argument is the existence of wounds on the Amazons ' bodies. The analysis of anthropological materials showed that the women had the injuries of the ,military" character. There are three types of injuries: 1 - the wounds made with arrows; 2 - loss or fractures of the extremities; 3 - chopped wounds on the skull and extremities. Thus the first type of the injuries (the wounds from arrows) is presented by three options: the damage of the bone tissue; the penetrating wound of the skull or the soft tissue damage. The burial complexes of the Scythian Amazons show that their injuries are quite diverse and therefore they have been obtained in different conditions. Quite important is the fact that these graves are fixed in the different regions of Scythia and indirectly point out the probable places of the armed clashes. Amazon graves with the traces of wounds are as well known in the Asian part of Scythia. Sarmatian women also had them.

Thus, in the issue of the excavations in various regions of the European Scythia it became obvious that there were women among the nomads, who clearly were not only caring weapons just as men (and along with them), but also took part in the military conflicts. It is due to the participation in the conflicts that these women were buried in accordance with the traditional funeral rites of Scythian warriors - following the same rituals with the same honors and, most importantly, with a personal weapon.

The chronological range of burial complexes of the female warriors, in general, is narrower than male's. The earliest burials of male warrior on the territory of the European Scythia refer to the 7th century BC and are known till the beginning of the 3rd century BC, while the earliest Amazons' graves date from the second half of the 7 th - the beginning of the 6th centuries BC. So burial complexes of the Scythian 
Amazons both in the territories of the nomads' direct habitat in the early Iron Age, and in the regions controlled by the Scythians or border regions, are dated in a relatively wide range - from the second half of 7 th till the 2 nd or even 1 st centuries BC. However, the main group of these graves confined to the 4th century BC.

One can hardly claim that there existed the Amazon Empire in North Pontic Area. Archaeological sources provide no evidence of them being fierce husbandkillers. And yet, when all sources compared, a lot of similarities is obvious.

And yet we may consider "amazonship" as the general-historical phenomenon. In any society where men are involved in armed conflicts, women should defend their home, family (children and old people), herds. Thus, while some women were involved in defending, others took part in fighting equally with men. It is typical for many nations actually in the course of the entire history of mankind.

\section{BIBLIOGRAPHY}

Andrukh S. I., Toshchev G. N.

1999 Mogilnik Mamay-Gora (vol. 1). Zaporozhye: Izdatelstvo Zaporozhskogo gosuniversiteta.

Andrukh S. I.

2001 Mogilnik Mamay-Gora (vol. 2). Zaporozhye: Izdatelstvo Zaporozhskogo gosuniversiteta.

Andrukh S. I., Toshchev G. N.

2004 Mogilnik Mamay-Gora (vol. 3). Zaporozhye: Zaporozhskiy gosudarstvennyy universitet.

Artamonov M. I.

1974 Kimmeriytsy i skify. Leningrad: Izdatelstvo LGU.

Berezovets D. T.

1960 Rozkopky kurhannoho mohylnyka epokhy bronzy ta skifskoho chasu vs. Kut. Arkheolohichni pamia'tky, 9, pp. 39-86.

Brashinskiy I. B.

1968 Raboty Yuzhnodonskoy ekspeditsii. Arkheologicheskiye otkrytiya v 1967 g. (pp. 88-89). Moskva: Nauka.

Brashinskiy I. B.

1973 Raskopki skifskikh kurganov na Nizhnem Donu. Kratkiye Soobshcheniya Instituta Arkheologii Akademii Nauk SSSR, 133, pp. 54-61.

Brashinskiy I. B., Demchenko A. I.

1969 Raskopki Elizavetovskogo mogilnika v 1966 g. Kratkiye Soobshcheniya Instituta Arkheologii Akademii Nauk SSSR, 116, pp. 11-117.

Bunyatyan E. P.

1982 Metodika sotsialnoy rekonstruktsii po dannym ryadovykh skifskikh mogilnikov. In: V. Gening (ed.), Teoriya i metodika arkheologicheskikh issledovaniy (pp. 136-184). Kiyev: Naukova dumka. 
Galanina L. K.

1985 K probleme vzaimootnosheniy skifov s meotami (po dannym novykh raskopok Kelermesskogo kurgannogo mogilnika). Sovetskaya Arkheologiya, 3, pp. 156-165.

Gorelik M. V.

1993 Oruzhiye Drevnego Vostoka (IV tysyacheletiye - IV v. do n.e.). Moskva: Vostochnaya literatura.

Grakov B. N.

1962 Skifskiye pogrebeniya na Nikopolskom kurgannom pole. Materialy $i$ issledovaniya po arkheologii SSSR (MIA), 115, pp. 56-113.

Gulyayev V. I.

2002 „Amazonki” na Srednem Donu. In: A. T. Sinyuk (ed.), Arkheologicheskiye pamyatniki Vostochnoy Evropy (pp. 125-134). Voronezh: Voronezhskiy gosudarstvennyy pedagogicheskiy universitet.

Gulyayev V. I.

2005 Rastsvet i padeniye velikogo tsarstva. Moskva: Aleteya.

Gulyayev V. I.

2010 Na vostochnykh rubezhakh Skifii (drevnosti donskikh skifov). Moskva: IA RAN.

Gulyayev V. I., Savchenko E. I.

2004 Novyy pamyatnik skifskogo vremeni na Srednem Donu. In: V. I. Gulyayev (ed.), Arkheologiya Srednego Dona v skifskuyu epokhu. Trudy Donskoy (b. Potudanskoy) arkheologicheskoy ekspeditsii IA RAN, 20012003 gg. (s. 35-52). Moskva: IA RAN.

Hanina O. D.

1958 Do pytannia pro zhinochi pokhovannia zi zbroieiu skifskoho chasu. Pratsi Kyivskoho Derzhavnoho Istorychnoho Muzeiu, 1, pp. 175-183.

Hanina O. D.

1960 O zhenskikh zakhoroneniyakh v parnykh pogrebeniyakh skifskogo vremeni. Zapiski Odesskogo arkheologicheskogo obshchestva, 1(34), pp. 96-104.

Hrytsiuk V. M.

2009 Viisko skifiv (ozbroiennia, orhanizatsiia, viiny ta voienne mystetstvo). Chernivtsi: Misto.

Kopylov V. P., Yakovenko E. V., Yangulov S. Yu.

2004 Pogrebeniya ,amazonok” v kurganakh Elizavetovskogo mogilnika. In: 2 Mezhdunarodnaya konferentsiya „Skify i sarmaty v 8-3 vv. do n.e.” (pp. 53-57). Azov Rostov-na-Donu: Yuzhnyy nauchnyy tsentr RAN.

Maksimenko V. E.

1983 Savromaty i sarmaty na Nizhnem Donu. Rostov-na-Donu: Izdatelstvo Rostovskogo universiteta.

Marchenko K. K., Zhitnikov V. G., Kopylov V. P.

2000 Elizavetovskoye gorodishche na Donu. Moskva: IA RAN.

Melyukova A. I.

1964 Vooruzheniye skifov. Moskva: Nauka.

Melyukova A. I.

1975 Poseleniye i mogilnik skifskogo vremeni u s. Nikolayevka. Moskva: Nauka. 
Okatenko V. N.

2006 Pogrebeniya kochevnicheskogo tipa skifskogo vremeni vdol Lesostepnogo otrezka Muravskogo shlyakha. Vestnik Kharkovskogo natsionalnogo universiteta im. V. N. Karazina, 38, pp. 78-90.

Popandopulo Z. H.

2011 Skifskiy gruntovyy mogilnik Skelki. Zaporozhye.

Prokopenko Y. A.

2014 Skify. sarmaty i plemena kobanskoy kultury v Tsentralnom Predkavkazye vo vtoroy polovine I tys. do n.e. (vol. 1). Stavropol: Severo-Kavkazskiy federalnyy universitet.

Prokopenko Yu. A.

2014a Skify. sarmaty i plemena kobanskoy kultury v Tsentralnom Predkavkazye vo vtoroy polovine I tys. do n.e. (vol. 2). Stavropol: Severo-Kavkazskiy federalnyy universitet.

Sinika V. S., Alemsha A. N.

2000 Zhenskiye pogrebeniya s oruzhiyem pozdneskifskogo mogilnika u s. Glinoye. In: Chobruchskiy arkheologicheskiy kompleks i drevniye kultury Podnestrovia (materialy polevogo seminara) (pp. 43-46). Tiraspol: RIO PGU.

Skoryy S. A.

1997 Steblev: skifskiy mogilnikv Porosye. Kiyev: Naukova dumka.

Fialko E. E.

1987 Skifskiye kurgany u s. Novoye. In: O. Shaposhnikova (ed.), Drevneyshiye skotovody stepey yuga Ukrainy (pp. 171-187). Kiyev: Naukova dumka.

Fialko E. E.

1991 Pogrebeniya zhenshchin s oruzhiyem u skifov. In: Yu. Boltrik. E. Bunyatyan (eds.),

Fialko E. E.

Kurgany Stepnoy Skifii (pp. 4-18). Kiyev: Naukova dumka.

2011 Dva pogrebeniya amazonok iz Severskodonetskoy Lesostepi. In: S. I. Posokhov (ed.),

Drevnosti Vostochnoy Evropy. Sbornik nauchnykh trudov k 90-letiyu B. A. Shramko (pp. 304-315). Kharkov: KhNU imeni V. N. Karazina.

Fialko E. E.

2012 Vooruzhennyye zhenshchiny rannego zheleznogo veka v Severnom Prichernomorye: sotsialnyy aspekt. Tyragetia. Arheologie. Istorie. Antica, VI [XXI], 1, pp. 27-44.

Fialko E. E.

2012 b

Skifskiy kurgan s antichnymi importami u s. Zelenoye. Bosporskiye issledovaniya, XXVI, pp. 218-254.

Fialko E. E.

2013 Seriya pogrebeniy amazonok iz Nizhnego Podneprovia. Stratum plus, 3, s. 203-222.

Fialko E. E.

2013 a Ukrasheniya v kostyume skifskikh amazonok. In: V. V. Klyuchnikov (ed.), Prichernomorye $v$ antichnoye i rannesrednevekovoye vremya. Sbornik nauchnykh trudov. posvyashchennyy 65-letiyu prof. V. P. Kopylova (pp. 231-241). Rostov-na-Donu: Nauchno-metodicheskiy tsentr arkheologii YuFU.

Fialko O. Ie.

2012 a Pokhovannia divchat zi zbroieiu v skifskomu kurhani na Khersonshchyni. Arkheolohiia, 1, pp. 82-92. 
Chernenko E. V.

1988 Voyennoye delo skifov (vooruzheniye. taktika. strategiya). Kiyev: Naukova dumka.

Chernenko Ie. V.

1991 Lytsari Velykoi Skifii. In: P. P. Tolochko (ed.), Zoloto Stepu. Arkheolohiia Ukrainy (pp. 131-135). Kyiv - Shlezvih: Instytut arkheolohii NAN Ukrainy, Arkheolohichnyi zemelnyi muzei Universytetu Kristiana-Albrekhta.

Yangulov S. Yu.

2007 Kompleksy vooruzheniy plemen Nizhnego i Srednego Dona v skifskoye vremya (sravnitelnyy analiz). In: Mezhdunarodnyye otnosheniya $v$ basseyne Chernogo morya $v$ drevnosti i sredniye veka. Materialy XII mezhdunarodnoy nauchnoy konferentsii (pp. 44-45). Rostov-na-Donu: Nauchno-metodicheskiy tsentr arkheologii RPI.

Yangulov S. Yu.

2008 Oruzhiye iz pogrebeniy 5 v. do n.e. Elizavetovskogo mogilnika v delte Dona. $R A, 1$, pp. 63-72.

Yangulov S. Yu.

2008a Vooruzheniye $i$ voyennoye delo skifov Nizhnego Dona (po materialam Elizavetovskogo mogilnika). Avtoreferat dyssertatsii kandydata istorychnykh nauk. Moskva.

Fialko E.

2012 Funerary Monuments of the Scythian Amazons (Social Aspect). British Archaeological Reports (BAR) International Series 2396. Tumuli Graves - Status Symbol of the Dead in the Bronze and Iron Ages in Europe (ed. V. Sirbu and C. Schuster). Proceedings of the XVI IUPPS World Congress (Florianopolis, 4-10 September 2011). Actes du XVI Congres Mondial UISPP (Florianopolis, 4-10 Septembre 2011), vol. 2, pp. 61-67.

Guliaev V. I.

2003 Amazons in the Scythia: new finds at the Middle Don, Southern Russia. World Archaeology, 35(1). The Social Commemoration of Warfare. Jun., 2003, pp. 112-125.

\section{SCYTHIAN FEMALE WARRIORS IN THE SOUTH OF EASTERN EUROPE}

S u m m a r y

On more than one occasion, Amazons are described as beautiful horsewomen and female warriors by famous heroes of ancient Greek mythology. Greeks very appreciated their fighting qualities and called the troops of the warrior women to help them during the battles with an enemy. The first detailed story about women- matricides (Óóo $\pi \alpha \tau \alpha$ ) was written by Herodotus.

In the second half of 20th century the interesting materials were found during the archaeological researches in the territory of Southern Ukraine, which was occupied by nomads. It became evident, that there were women among the nomads, who clearly were not only caring weapons just as men (and along with them), but also took part in the military conflicts. Amazons were therefore buried as valorous fighters. The burials of women with weapons are widely present throughout the 
south of The Eastern Europe. On the lands of the South of Ukraine the burials of female warriors consist a quarter of a number of all Scythian burials with weapons. In the territories of Pontic Steppe armed women burials are dated to the second half of $7^{\text {th }}-2$ nd century BC. We can distinguish three main clusters. Many burials of armed women of this period are known on the lands of the Don River as well as on the other territories.

One can hardly say that the country of Amazons existed on the Northern Black Sea coast. Archaeological researches do not give a picture about the irreconcilable matricides. However, if we compare the descriptions of the ancient authors with the archaeological material we could clearly see the series of matches. And yet we may consider "amazonship" as the general-historical phenomenon. 